\title{
English Major Students' Self-Concept Perspective on Viewing Translator as a Profession
}

\author{
Dahlia Husain ${ }^{a, *}$, Bahar $^{\mathrm{b}}$ \\ ${ }^{a}$ Muhammadiyah University, Gorontalo, Indonesia \\ ${ }^{b}$ Fajar University, Makasar, Indonesia \\ *Corresponding author:dahliahusain@umgo.ac.id
}

\begin{abstract}
This paper reports on research conducted to explore English major students' views on becoming a translator as their future profession. The focus is divided into three main concerns; do the students consider translator as their profession after graduation? 2) do the students think they are equipped with enough knowledge on becoming a translator? 3) what elements should the English Department provide to support their career choice? These concerns were presented in a perceptional questionnaire as the main data collection technique that aims to find out whether the students of English Literature at the University of Muhammadiyah Gorontalo would consider translator as their career. This is qualitative research with total sampling as the technique of data collection. The subjects of the research were 20 students of 6th semester majoring in English Literature at the Muhammadiyah University of Gorontalo. The result of the study showed that the students have moderate consideration in choosing translation as their career path. There are several reasons behind such thoughts, one of which is they do not think they qualified for becoming a professional translator or choosing the line of work as their future profession. Last, they think that the faculty can provide more classes on translation to build both their skills and their confidence in becoming future translators.
\end{abstract}

Keywords: students's self-concept, perspective, translator

\section{INTRODUCTION}

In Indonesia, we have some levels of formal educational institutions such as SD, SMP, SMA, university, and so on. This level of education provides a wide range of different materials or subject matters. The knowledge obtained is different. The higher the level the education has taken means the wider the knowledge that the students have access to. Higher education will provide opportunities for the community to obtain knowledge and information about issues development widely. It can raise awareness, attention, and understanding toward one's role and contribution to a bigger cause. For most of us, a university education is a privilege that can determine the future endeavour. Some students even choose their specialty earlier since they are in their high school, such as to go into public, private, Islamic, or even vocational high school that is more specific to a certain major. Nonetheless, it is the specialty they choose in university that most influence their profession later on.

The phase of choosing a major for students is a moment that determines the future in every phase of life. Choosing a major for their university education for some people can both be very complicated and complex, yet this also brings certain consequences and risks. Ruslan 
(2012: 76) states that "taking a career is not born solely from fantasy and wishful thinking, but career is closely related to education." Furthermore, Al-Mighwar (2006: 104) stated that in adolescents, the more they find the connection of a subject to their future work, the more amount of interest they have in said subject. In general, adolescents are more interested in the subject matter when later it will be useful in the field of work he chooses. It can be interpreted that the selection of majors is a process to approach the field of work that the student wanted as their profession when they finish college.

This paper discusses how English major students' prospected on being a translator as their future career. A translator is defined as someone who can combine both being a writer and a linguist. The job of a person who claims to be a translator may look simple, which is to transform any written document to another language intact. This gives the idea that they take written material such as documents, paper, newspaper, magazine articles, books, manuals that are presented in one language and change them into the equivalent in another language. In the same sense, a translator's main job is transferring a written document from one language to the other language proportionally without losing its bottom line. Therefore, a translator should be fluent in at least two languages, and they can or are suggested to know a third or even fourth other languages in the same capacity (Suyono \& Hariyanto, 2014).

Regarding with skills that a translator should have, first, any translator should have two skills which are writing and reading. A translator should own strong reading and writing skills in both languages being translated to and being translated from. Second, since every major have their specific language or terms, a translator also should possess a deep knowledge of the subject material or their field. Most commonly, a translator works within their native language and translates them to the second language they fluent in.

Having solid writing and reading skills is crucial to anyone within the language business such as editor, reviewer, and so on but in the translation field, these two skills are fundamental. In becoming a translator, the activity of re-reading a document, editing, and revision tasks are often seen as an integral part. The importance of editing and revision is often seen as a requirement in the translation workflow for quality assurance purposes. Unfortunately, there have been some reports on how the translator is mostly not doing the translation steps. Saksono (2013) was studying the problems in novice translator in Madura claimed that they do not acknowledge that a translator is one profession which involves multi competences. The translation training model which is done by translators in Madura tends to transfer only the structure of the Source Text into the Target Text.

So the question is, how can students major in English studies view themselves working as a translator as their future career? Concerning educational background and translation as a profession, Christian's study (2015) revealed that the research findings show that Translator 1 who has special formal education in translation and although has the least experience in translating is able to produce high-quality translations, namely 2.70 (High) for business texts and 2.79 (High) for legal texts. On the contrary, Translator 1 and Translator 2 who have long experience in translation, but have no formal education on translation can only produce a medium quality translation, sequentially 2.40 (moderate) for Translator 2 and 2.53 (moderate) for translator 3 for both in business and legal text. His study concluded that the background of the translator influenced the quality of the translation results and that based on his findings, the length of time working as a translator is not the main key to a translator's reliability in producing quality translations.

When one talking about a career path, they surely mean whether they can make money out of that profession, or will that profession pays the bill. Saifudin (2013) studied exploration of the entrepreneurial potential that can be developed in translation as a career path. His 
research method uses qualitative paradigm field research with the aim of explaining the entrepreneurial potential of becoming a translator. The data were collected using subject observation and informant interviews. He claimed that this study is specifically targeted to provide the students with knowledge about the potential of entrepreneurship and the long-term target is to provide a basis for further research on entrepreneurial-based translation learning models. The results show the great potential in entrepreneurial development, such as the potential for the profession as a translator, interpreters, and film translators.

This study aims to examine the students' perception of making a career out of translation. It asks a global question on the students' perception toward becoming a translator. It will answer three particular questions; 1) How do students majoring in English consider translator as their future profession? 2) How are the student's views on whether or not they are equipped with enough knowledge on becoming a translator?

\section{METHOD}

The present study includes twenty participants of the 6th-semester student at the Muhammadiyah University of Gorontalo. The 6th-semester students of English Literature were only submitted into one class. This class was chosen as samples of research because they met certain criteria that in line with this research, 1) They have taken and have passed both translation class and interpreting class, 2) Researchers have several classes with them before. It will make it easier to collect the data 3) There are twenty students this semester and they are all taken as participants of research. The sample taken was total sampling due to the reason above.

A questionnaire was carried out to the students of the 6th semester to examine students' perception of the Muhammadiyah University of Gorontalo. There are 15 items in this 5-point Likert scale questionnaire that will unveil students' perception toward becoming a translator and viewing them as a career path.

A perception questionnaire was created with the intention of understanding the students' perception toward becoming a translator and viewing them as a career path. The students are asked to give their responses to the fifteen items in the questionnaire based on their data gained from the students' responses was, then analyzed using the SPSS program.

The data were taken in Mei 2020. During the administration of the questionnaire, the researcher explains to the students the concept of perception. The researcher clarifies the questionnaire and makes sure that the students understood each item in the questionnaire. Students were asked to rate each item based on a scale from Never, Seldom, Sometimes, Often, and Always. After that, the overall result was computed.

\section{FINDINGS AND DISCUSSION}

There are three key topics that become the center of this research;1) Why the students consider translator as their profession after graduation? 2) How the students think they are equipped with enough knowledge on becoming a translator? 3) What elements should the English Department provide to support their career choice? Each of these key topics is further distributed into fifteen numbered questionnaire, which means that each key topic is elaborated into five questions each. The data were presented below: 
Table 1. Data on Key Topic 1

\begin{tabular}{|c|c|c|c|c|c|c|c|}
\hline Key Topic 1 & $\begin{array}{l}\text { Item } \\
\text { number }\end{array}$ & Never & Seldom & Sometimes & Often & Always & Total \\
\hline How do students & 1 & & $30 \%$ & $50 \%$ & $20 \%$ & & $100 \%$ \\
\hline majoring in & 2 & & $50 \%$ & $40 \%$ & $10 \%$ & & $100 \%$ \\
\hline consider translation as & 3 & & $40 \%$ & $40 \%$ & $20 \%$ & & $100 \%$ \\
\hline their future profession? & 4 & & $40 \%$ & $30 \%$ & $30 \%$ & & $100 \%$ \\
\hline & 5 & & $10 \%$ & $50 \%$ & $40 \%$ & & $100 \%$ \\
\hline
\end{tabular}

The data in Table 1 elaborates on whether or not the students thought of becoming a translator after graduating from the university. That idea is then being elaborated on from question 1 to question 5. The result showed that the students in fact did not really think of becoming a translator when they graduate. This can be seen by none of the students have the high-frequency answer from questions 1-5. It can be seen from the table that the choice "often" is not favored, most students answer to all the questions were distributed between "sometimes" and "seldom", this indicates that they have other professions on their mind instead of choosing a translator as their career path. The table above can be inferred as the students have moderate consideration on choosing translation as their future profession. This signifies that becoming a translator is not quite favored. Nonetheless, in China, the needs for translators have increased to a certain level that demanded the universities to open translation and interpreting major. It triggers a study on what motivates Chinese students to pursue a career as a translator. As a case study, Liu and $\mathrm{Yu}$ (2019) research may not be generalized yet, but the study reveals that program instructors strongly affect the students' motivation because of their expertise.

Meanwhile, in the Indonesian context, translation is not yet an independent study. It was only embedded in the curriculum as a part of the course. Should we accept the idea that becoming a translator is students' goal, then it is reasonable to conceive that they wanted this goal to be fully supported by the institution that reflects in the curriculum for instance? In the Muhammadiyah University of Gorontalo for example, the curriculum of English literature study from the year 2012-2016 has only one subject for translation and interpreting. Only after that, in the current curriculum, the two subjects have been separated into two different subjects. Asker (2012) in his research found that students constantly negotiate the relationship between their L2 learning experience and their future selves. Therefore, only having one class in translation can be said contributes to the fact that students have only moderately considered becoming translators after they graduate.

Table 1. Data on key topic 2

\begin{tabular}{|c|c|c|c|c|c|c|c|}
\hline Key Topic 2 & $\begin{array}{l}\text { Item } \\
\text { number }\end{array}$ & Never & Seldom & Sometimes & Often & Always & total \\
\hline How are the students view & 6 & & & $20 \%$ & $40 \%$ & $40 \%$ & $100 \%$ \\
\hline on whether they are & 7 & & & $30 \%$ & $40 \%$ & $30 \%$ & $100 \%$ \\
\hline equipped with enough & 8 & & & $40 \%$ & $40 \%$ & $20 \%$ & $100 \%$ \\
\hline knowledge on becoming a & 9 & & $40 \%$ & $30 \%$ & $30 \%$ & & $100 \%$ \\
\hline translator & 10 & & $50 \%$ & $30 \%$ & $20 \%$ & & $100 \%$ \\
\hline
\end{tabular}

The data in Table 2 elaborates on whether or not the students think they are equipped with enough knowledge on becoming a translator. This study revealed that in relation to abilities that any translator should have, the students admit that they still lack some of it as 
Saksono (2013) states on the problems in novice translator in Madura that they do not acknowledge that a translator is one of the professions which involve multi competences. Unfortunately, as has been mentioned before, translation is only served as a subject that was embedded in English education or English literature program, mainly as compulsory subjects. Therefore, equipping the students with mandatory insight into translation study is quite hard.

Moreover, Dewi's research (2019) revealed how left behind Indonesia is in terms of the trends going on in the translation studies. Even some universities that have translation programs as in some parts of Java and Bali have only touched topics such as text analysis and productoriented translation studies. Meanwhile, very limited research belonged to the process-oriented translation research. This situation indicates how left behind we are in TS research and conclude the notion that our TS research is not developed well, and has not varied when compared to the international TS research progress.

Table 2. Data on Key Topic 3

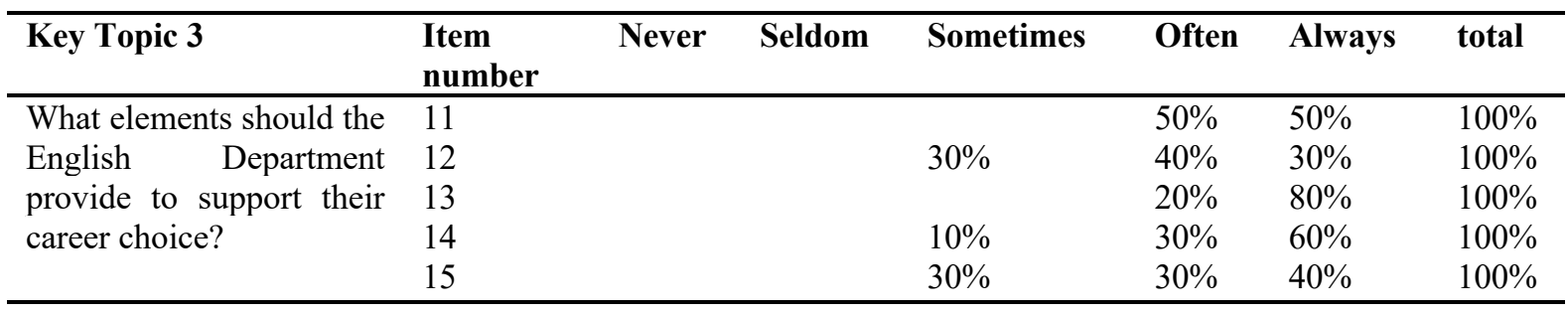

The data in Table 3 provides information on what elements do students thinks the department, to the faculty level, should improve to support their future career choice. Question 10-15 elaborates how students think of some things they wanted to be provided, added, develop, or modified by the faculties in order for them to have a higher chance of increasing their capacities for their future endowment. Students can actually be whatever they put their mind to, yet every profession always requires a set of skills that they need to master. On the other hand, good translation education, professional development, and foreign language competence can make a good contribution and acceleration for a translator to become a translator who is reliable and has high selling power. Nonetheless, since the demand for translation as a profession has increased, the university needs to take some actions to serve this matter. A curriculum workshop specifically designed to accommodate this problem can be an alternative solution involving translation-based curriculum designers, stakeholders, and translation service providers. As to what can be done by the teacher of translation at this time, a study by Del Mar Haro-Soler, (2017) suggested that teachers should provide several conditions such as giving positive and constructive feedback, student-centered approach learning, scaffolding, a continuous assessment system, and so forth. Sandra (2018) also suggested that identifying problems and strategies of EFL student in translation is prominent to help pinpoint which elements in the English language that should be highlighted to prepare students for the world of translation. 


\section{CONCLUSION}

The study was performed with the general objection to shed light on the way students view translator as their future career, and how do they think of the knowledge they have to support this profession. A perception questionnaire was administered and the study was analyzed qualitatively. The result showed that students have a moderate interest in becoming a translator or pursue a career in translation studies. Some major issues that contribute to the problem are for instance how translation is only viewed as a subject in most universities in Indonesia rather than an independent major. Therefore, it is suggested that the development of a curriculum that accommodates the abilities that match the need of a professional translator needs to be done. This is also an important move to make sure that the Indonesian translation research does not fall behind compared to the world's translation research.

\section{REFERENCES}

Al-Mighwar M. (2006). Psikologi Remaja. Bandung: CV Pustaka Setia.

Asker, A. (2012). Future self-guides and language learning engagement of English-major secondary school students in Libya: Understanding the interplay between possible selves and the L2 learning situation. Doctoral Dissertation, University of Birmingham.

Christian, D. S. (2015). Studi Kasus Profil Penerjemah Semi-profesional Berlatar Belakang Pendidikan Penerjemahan dan Tanpa Latar Belakang Pendidikan Penerjemahan serta Kualitas Hasil Terjemahan Mereka. Doctoral dissertation, UNS (Sebelas Maret University).

Del Mar Haro-Soler, M. (2017). Teaching Practices and Translation Students' Self-efficacy: A qualitative study of teachers' perceptions. Current Trends in Translation Teaching and Learning E, 4, 198-228.

Dewi, H. D. (2019). Translation Studies Research Development in Indonesia. Jurnal Humaniora, 31(2), 152-165.

Liu, C., \& Chengyuan, Y. (2019). Understanding students' motivation in translation learning: a case study from the self-concept perspective. Asian-Pacific Journal of Second and Foreign Language Education 4.1: 4.

Ruslan, R. (2012). Manajemen Public Relations dan Media Komunikasi; Konsep dan aplikasi. Jakarta: Raja Grafindo Persada

Saifudin, A. (2013). Potensi Kewirausahaan dalam Pembelajaran Penerjemahan. Semantik, 3(1).

Saksono, S. T. (2013). Penguatan Pelatihan Penerjemahan Bagi Penerjemah Pemula Sebagai Upaya Peningkatan Kualitas Penerjemah di Madura. Prosodi: Jurnal Ilmu Bahasa dan Sastra, 7(1).

Sandra, R. A. (2018). From English to Indonesia: Translation problems and strategies of EFL student teachers-A Literature Review. International Journal of Language Teaching and Education, 2(1), 13-18.

Sela-Sheffy, R. (2005). How to be a (recognized) translator: Rethinking habitus, norms, and the field of translation. Target. International Journal of Translation Studies, 17(1), 126.

Suyono, A., \& Hariyanto, S. (2014). Perkembangan Teknologi Informasi dan Profesi Penerjemah. Jurnal Linguistik Terapan, 4(2), 56-62. 